\title{
SARS-CoV-2: GENETIC VARIABILITY, MUTATIONS AND VARIANTS OF CONCERN FOR THE GLOBAL WORLD
}

\section{SARS-CoV-2: GENETIČKA VARIJABILNOST, MUTACIJE I VARIJANTE KOJE ZABRINJAVAJU GLOBALNI SVET}

\author{
Maja Ćupić ${ }^{1}$
}

${ }^{1}$ Univerzitet u Beogradu, Medicinski fakultet, Institut za mikrobiologiju i imunologiju, Beograd, Srbija

Correspondence: maja.cupic@med.bg.ac.rs

\section{Abstract}

Since emerging from Wuhan, China, in December of 2019, the novel coronavirus named SARS-CoV-2 has been causing devastating severe respiratory infections in human population worldwide. The new emerging disease was called COVID-19 and, as early as the beginning of 2020, the world found itself in a COVID 19 pandemic. Despite the slow evolutionary rate of SARS-CoV-2 relative to other RNA viruses, its massive and rapid transmission during the COVID-19 pandemic has enabled it to acquire significant genetic diversity since it first entered the human population. This led to the emergence of numerous variants, some of them recently being labeled, "variants of concern" (VOC). Emerging SARS-CoV-2 variants can be problematic if one or more of the independent mutations result in changes that make the virus more pathogenic, resistant to treatment, able to escape vaccines, or able to evade diagnostic tests. So far, four VOCs have been globally recognized (Alpha or B.1.1.7, Beta or B.1.351, Gamma

Keywords:

SARS-CoV-2,

COVID-19,

mutational petterns, main variant of concern,

B.1.1.7,

B.1.351,

P.1,

B.1.617 or P.1 and newly recognized as VOC Delta or lineage B.1.617.2), and areas of the emerging variant of concern first time observed are United Kingdom, South Africa, Brazil, and India, respectively.

Notable variants are those that contain mutations within the $S$ gene, particularly within the region that codes for the receptor-binding domain (RBD) that recognize and attach the specific ACE2 cell receptor. These mutations are responsible for increased viral transmission and influence disease severity, reliability of clinical tests as well as vaccine and therapy efficacy. The characteristics of VOCs and their mutational patterns indicate the necessity of permanent close monitoring on a global level.
Ćupić M. MedPodml 2021, 72(3):1-7

(c)

The authors declare no conflicts of interest. doi:10.5937/mp72-33322

Editorial board: podmladak.med.bg@gmail.com e-ISSN: 2466-5525 


\section{Sažetak}

Otkako je otkriven u Vuhanu u Kini, decembra 2019. godine, novi koronavirus, nazvan SARS-CoV-2, izaziva razarajuće teške respiratorne infekcije kod ljudi širom sveta. Nova preteća bolest nazvana je COVID-19 i već početkom 2020. godine svet se našao u pandemiji. Uprkos sporoj evolutivnoj stopi SARS-CoV-2 u odnosu na druge RNK viruse, njegov masovni i brzi prenos tokom COVID-19 pandemije omogućio mu je da stekne značajnu genetsku raznolikost od kada je prvi put ušao u ljudsku populaciju. To je dovelo do pojave brojnih varijanti, od kojih su neke nedavno nazvane ,,varijantama koje zabrinjavaju“ (VOC). Nove varijante SARS-CoV-2 postaju problem ako jedna ili više nezavisnih mutacija rezultira promenama koje virus čine patogenijim, otpornijim na terapiju, sposobnim

Ključne reči:

SARS-CoV-2, COVID-19, obrasci mutacija, glavne varijante koje zabrinjavaju, B.1.1.7, B.1.351, P.1, B.1.617 da izbegne dejstvo vakcina ili izbegne dijagnostičke testove. Do sada postoje četiri globalno prepoznate VOC (Alfa ili B.1.1.7, Beta ili B.1.351, Gama ili P.1 i nova prepoznata kao VOC Delta ili B.1.617.2 varijanta), dok su područja odakle su prvi put VOC identifikovane: Ujedinjeno Kraljevstvo, Južna Afrika, Brazil i Indija.

Značajne varijante su one koje sadrže mutacije unutar $S$ gena, posebno u regionu koji kodira receptor vezujući domen (engl. receptor binding domen, RBD) koji prepoznaje i vezuje specifični ACE2 receptor na ćeliji. Ove mutacije su odgovorne za povećanu prenosivost virusa, utiču na težinu bolesti, pouzdanost kliničkih testova, kao i na efikasnost vakcine. Karakteristike VOC i njihovi mutacijski obrasci ukazuju na neophodnost njihovog permanentnog veoma pažljivog praćenja na globalnom nivou.

\section{Uvod}

Iako je scenario o pojavi novih (engl. emerging) patogena, uzročnika humanih infekcija, u trećem milenijumu zbog globalnih promena na zemlji, posebno zbog narušavanja prirodno izbalansiranih odnosa u ekosferi, bio sasvim izvestan i očekivan, svet je ipak ostao zatečen iznenadnom pojavom novog virusnog patogena, koji je identifikovan početkom 2020. godine. Sve je počelo dva meseca ranije, tačnije decembra 2019. godine u gradu Vuhanu, u provinciji Hubej u Kini, masovnim razboljevanjem ljudi sa kliničkim slikama teških pneumonija nepoznatog porekla (1). Vrlo brzo je kao uzročnik identifikovan novi koronavirus, nazvan koronavirus-2, udružen sa teškim akutnim respiratornim sindromom (SARS-CoV-2), a nova bolest je dobila naziv koronavirusna bolest 2019 (COVID-19) (2). Od tada život na Zemlji nije isti kao ranije.

Virus se širio svetom veoma brzo i Svetska zdravstvena organizacija (SZO) je 11. marta 2020. godine proglasila pandemiju COVID-19 (3). SARS-CoV-2 se masovno i rapidno širio planetom i doveo do milionskih brojki obolevanja ljudi, smrtnih ishoda, preležanih infekcija uz kompletan oporavak pacijenata, ali i po prvi put stanja prepoznatih kao postkovid sindrom, novog entiteta dugotrajnih, hroničnih stanja, sekvela, nakon preležane bolesti (4). O SARS-CoV-2 se izveštava u 220 zemalja sveta. Do druge polovine jula 2021. godine od početka pandemije virus je registrovan kod više od 190 miliona ljudi , preko 4 miliona je umrlo, a više od 175 miliona se oporavilo (5). Ove cifre jasno ukazuju da je COVID-19 postao zdravstvena, socioekonomska i kulturološka paradigma savremenog života na planeti.

I pored postojanja većeg broja vakcina, dizajniranih na različitim platformama, koje su veoma brzo od proglašenja pandemije postale dostupne $\mathrm{u}$ imunizaciji globalnog stanovništva, virus je i dalje aktivan i prisutan u svetskoj populaciji, što mu obezbeđuje da se neprekidno menja i $\mathrm{u}$ vidu različitih varijanti nastavlja da se u masovnim epidemijskim talasima širi svetom. U ovom trenutku, u pandemiji COVID-19, cirkuliše više varijanti SARS-CoV-2. Mutacije, pre svega u genu koji kodira površinski proteinski izdanak u vidu šiljka (engl. spike), odgovoran za vezivanje virusa za ciljne ćelije, a time za otpočinjanje infekcije, koji je istovremeno target za prirodni i vakcinalni imunski odgovor, izazivaju zabrinutost da aktuelne vakcine, uspeh terapije monoklonskim antitelima i antivirusna terapija ostanu neefikasni. Takođe, određene varijante virusa izbegavaju da budu identifikovane postojećim panelima dijagnostičkih testova (6).

Ceo svet se našao pred zahtevom kontinuiranog monitoringa genetičkih promena i identifikacije mutacija koje koreliraju sa novim $\mathrm{i} /$ ili izmenjenim osobinama virusa, kao i otkrivanja novih cirkulišućih SARS-CoV-2 varijanti radi što efikasnije i efektivnije borbe u zaustavljanju i prevazilaženju fenomena COVID-19.

\section{Osnovne odlike koronavirusa}

Koronavirusi prvi put su izolovani tridesetih godina prošlog veka kao uzročnici respiratornih (RT) i gastrointestinalnih infekcija (GIT) kod životinja. Trideset godina kasnije su otkriveni prvi humani koronavirusi koji su se dugo povezivali sa blagim, samoograničavajućim RT i GIT infekcijama ljudi, sve do pojave dva nova visokopatogena koronavirusa tokom prve dve decenije 21. veka. Radilo se o koronavirusu - uzročniku teškog akutnog respiratornog sindroma (engl. Severe Acute Respiratory Syndrome Coronavirus, SARS-CoV) i koronavirusu Srednjeg istoka, uzročniku respiratornog sindroma (engl. Middle East Respiratory Syndrome Coronavirus, MERS-CoV), koji su 2002, odnosno 2012. godine u zemljama u kojima su prvi put registrovani (Kina i Saudijska Arabija), kod ljudi 
izazvali teške akutne infekcije donjih partija respiratornog trakta, sa visokom stopom letaliteta $(7,8)$. Radilo se o animalnim koronavirusima čiji su prirodni rezervoari određene vrste slepih miševa koji su se, pre nego što će preskočiti barijeru vrste i ući u humanu populaciju, visoko adaptirali za ovaj događaj u drugom prelaznom animalnom domaćinu (9).

Iako se u skorijoj prošlosti ulazak u humanu populaciju viskopatogenih "emerging" koronavirusa odigrao dva puta, po identičnom scenariju, ovi događaji ipak nisu bili dovoljno upozoravajući za čovečanstvo da se mogu ponoviti. Upravo se to i desilo i novi koronavirus je načinio i treći skok kojim je, isto kao i prethodna dva puta, iz zoonotskog sveta ušao u svet ljudi, prethodno u prelaznom animalnom domaćinu veoma dobro pripremljen da što efikasnije nastavi osvajanje i opstanak u populaciji čoveka (10). Analize genoma poslednja tri identifikovana koronavirusa ukazuju da između njih postoji visok stepen genomske srodnosti i to 79\% između SARS-CoV-2 i SARS-CoV, a nešto manje ( 50\%) između novog SARSCoV-2 i MERS-CoV. I pored visoke genomske homologije SARS-CoV-2 i SARS-CoV, razlika na nivou receptor vezujućeg domena (engl. receptor binding domen, RBD) u "spike" proteinu čini novi koronavirus transmisivnijim, sa većom brzinom širenja, jačim afinitetom vezivanja za receptor na ciljnim ćelijama i većim replikativnim fitnesom (11). Ipak, najveći stepen homologije od čak $96 \%$ postoji između SARS-CoV-2 i koronavirusa određene vrste tzv. potkovičastih slepih miševa RaTG13 Rhinolophus affinis, što jasno ukazuje na poreklo SARS-CoV-2 $(9,12)$.

Organizacija i struktura genoma SARS-CoV-2 i površinskog "spike" proteina

Virus SARS-CoV-2 pripada porodici Coronaviridae iz reda Nidovirales, potporodici Orthocoronavirinae i rodu $\beta$-koronavirusa. Koronavirusi su sferične partikule, veličine 80 - $120 \mathrm{~nm}$ u prečniku, koje zbog vertikalnih projekcija $\mathrm{u}$ vidu šiljaka, koje polaze sa virusnog omotača, daju izgled virusnim česticama sunčeve korone, što je i determinisalo njihov naziv (13).

Genom koronavirusa je $\mathrm{u}$ formi jednolančane pozitivne RNK (, , “ ssRNK) i predstavlja jedan od najdužih genoma među RNK virusima koga čini 30.000 nukleotida. Prve dve trećine genoma, počev od 5' neprepisujućeg UTR kraja, čine ORF1a i ORF1ab geni, tzv. replikaza kompleksa, koji kodiraju poliproteine ppla i pplab, koji se autokatalitičkom razgradnjom cepaju na 16 nestrukturnih proteina (nsp1 - 16) koji imaju višestruke uloge u transaktivaciji drugih virusnih gena, transkripciji i replikaciji genoma. Takođe, produkti nestrukturnih gena su involvirani u imunsku modulaciju i izbegavanje mehanizama urođene imunosti (14). Poslednju trećinu virusnog genoma čine geni koji kodiraju četiri strukturna proteina virusa: S (glikoproteinski izdanci omotača virusa u vidu šiljaka - "spike" protein), E (proteini omotača, engl. envelope), M (transmembranski glikoprotein) i N (nukleokapsidni protein), kao i set akcesornih gena $(15,16)$. S gen kodira istoimeni $S$ protein, najprominentniji deo virusne partikule koji virusu obezbeđuje pripajanje i ulazak u ciljnu ćeliju. Proteini $\mathrm{M}$ i E, produkti M i E gena, odgovorni su za nastanak virusnog omotača tokom finalnih faza životnog ciklusa virusa, odnosno sklapanja i napuštanja ćelije. E protein ima važnu ulogu u patogenezi COVID-19 jer vezuje humani PALS1 protein, koji je ključan u biogenezi adherencije i uspostavljanju polariteta u epitelnim ćelijama. Najzad, N protein, produkt $\mathrm{N}$ strukturnog gena, učestvuje u formiranju spiralnog ribonukleokapsida (17).

Set akcesornih gena kodira proteine sa ulogom ometača signalnih puteva u ćeliji i izbegavanjem dejstva interferona, kao jedne od prvih linija odbrane pokrenute urođene imunosti u toku rane, virusom izazvane infekcije (18).

Šiljati izdanak (engl. spike) je transmembranski glikoprotein na površini virusa $u$ vidu homotrimera, koji je izgrađen od tri istovetne jedinice. Postoji visok stepen sličnosti $\mathrm{u}$ aminokiselinskom sastavu $\mathrm{S}$ proteina humanog koronavirusa i koronavirusa drugih animalnih vrsta (civet mačke $~ 77 \%$, slepih miševa $75-98 \%$ i pangolina 92\%) (11). Sastoji se od S1 i S2 podjedinice. Podjedinica $\mathrm{S} 1$ je komponovana od $\mathrm{N}$-terminalnog domena (NTD) i RBD, koji igra esencijalnu ulogu u vezivanju za specifični ćelijski receptor, angiotenzin konvertujući enzim 2 (ACE2) (19). Takođe, RBD je target za imunski sistem (humoralni i T-ćelijski odgovor), kao i za antivirusne lekove. Unutar RBD se nalazi region označen kao receptor vezujući motiv (engl. receptor binding motif, RBM) koji predstavlja visoko varijabilnu strukturu unutar spajka, što je posebno važno za vezivanje sa ACE2 (20). Druga, S2 subjedinica takođe se sastoji od više delova i to su: fuzioni protein (FP), heptapeptidni domeni -1 i -2, transmembranski i citoplazmatski domen (21).

$S$ protein egzistira u otvorenoj i zatvorenoj formi. Kada je zatvoren RBM je sakriven, dok u otvorenoj konformaciji RBM, kao deo RBD, prominira iznad homotrimerskih jedinica šiljka, čime je virusu omogućeno vezivanje za ACE2, kao inicijalni korak u otpočinjanju infekcije. Sledeći korak je ulazak virusa procesom fuzije omotača sa ćelijskom membranom, posredstvom S2 subjedinice (22).

"Spike" u nativnoj formi egzistira kao inaktivni prekursor S1 i S2 subjedinice, koje su nekovalentnim vezama spojene $\mathrm{u}$ prefuzionoj fazi. $\mathrm{S}$ protein se po vezivanju za receptor na ciljnoj ćeliji cepa aktivnošću ćelijskih proteaznih enzima: furina i transmembranske serin proteaze (TMPRSS2). Ovo cepanje uslovljava ireverzibilne konformacione promene u spajku koje su krucijalne za ulazak virusa u ćeliju (23).

Jedinstvenost genomske organizacije SARS-CoV-2 je postojanje kratke $R R A R$ sekvence, koja upravo na mestu veoma preciznog polibaznog cepanja S proteina uslovljava inserciju četiri aminokiseline koje čine motiv koji prepoznaje furin proteaza. Smatra se da upravo ovo cepanje destabilizuje SARS-CoV-2, dovodeći do konformacionih promena, neophodnih da bi se RBD vezao za receptor (24). Uporedne analize genoma SARS-CoV-2 i drugih srodnih animalnih koronavirusa upućuju na jedinstvenost ovoga 
događaja samo u slučaju humanog SARS-CoV-2, sa izuzetkom koronavirusa jedne vrste slepih miševa Rhinolophus malazanus (RmYN02), gde se takođe na mestu polibaznog cepanja insertuju tri aminokiseline (25). Upravo ova sličnost jasno pokazuje da je S protein ključni igrač ne samo u patogenezi infekcije već i u evoluciji koronavirusa, obezbeđujući mu da inficira različite vrste, evolutivno se prilagođava novom domaćinu i relativno jednostavno prelazi iz vrste u vrstu (26).

Genetička varijabilnost i glavne varijante SARS-CoV-2 koje zabrinjavaju

Od proglašenja pandemije desile su se hiljade mutacija u genomu SARS-CoV-2. Kako je virus putovao planetom i kako je već dugo prisutan u humanoj populaciji, stekli su se uslovi da permanentno menja svoj genetski kod, zbog čega se čovečanstvo susreće sa pojavom novih virusnih varijanti koje koreliraju sa novim, po virus veoma povoljnim osobinama koje mu obezbeđuju prolongirano prisustvo među ljudima. Pojava novih varijanti virusa posledica je mutacija u virusnom genomu. Poznato je da je stopa mutacija RNK virusa značajno viša u odnosu na viruse sa DNK genomima, što je uglavnom posledica nepopravljivih grešaka koje $\mathrm{u}$ toku RNK replikacije pravi RNK zavisna RNK polimeraza (27). U suprotnosti sa navedenim, SARS-CoV-2 kao RNK virus i ima relativno nisku stopu mutacija, zahvaljujući reparativnoj sposobnosti njegove RNK zavisne RNK polimeraze, koja svojom 3'-5' egzonukleznom aktivnošću (nsp14) popravlja greške i time igra ključnu ulogu u limitiranju SARS-CoV-2 stope mutacija, koje se registruju sa učestalošću od $\sim 1 \times 10^{-3}$, tj. 1:1000 supstitucija po mestu/godini (6). Ipak, pojava velikog broja SARS-CoV-2 varijanti očigledno je posledica akumulacije mutacija koje utiču na transmisivnost virusa, njegov ćelijski tropizam i patogenost, što predstavlja ozbiljan izazov za efikasnost trenutnih vakcina, antivirusnu terapiju i dijagnostičke testove (13).

Tokom prve polovine 2020. godine raznolikost među sekvencama SARS-CoV-2 bila je mala. Najranija mutacija spajk proteina D614G SARS-CoV-2 u Evropi identifikovana je januara 2020. godine u Nemačkoj. Od tada je soj koji nosi D614G postao dominantna varijanta pandemije u većini zemalja, verovatno zato što je ova mutacija omogućila efikasniju transmisiju i veću infektivnost u odnosu na originalni vuhanski soj (28).

Pojava sve većeg broja SARS-CoV-2 varijanti nametnula je potrebu za generisanjem internacionalnih baza sa ogromnim brojem prijavljenih sekvenci iz celog sveta. Globalna inicijativa za deljenje svih podataka o gripu (engl. Global Initiative on Sharing All Influenza Data, GISAID), Nextstrain i PANGO predstavljaju trenutno tri važeća sistema nomenklature SARS-CoV-2 koje ih klasifikuju na varijante i klase kako bi se pratilo kretanje i pojava novih varijanti na globalnom nivou $(29,30)$.

Da bi se izbegla stigmatizacija porekla određene varijante u odnosu na geografsko područje iz koga potiče, Svetska zdravstvena organizacija (SZO) je 31. maja 2021. godine uvela novu nomenklaturu za SARS-CoV-2 varijante prema grčkom alfabetu (31).

Ukoliko nova, "emerging" SARS-CoV-2 varijanta poseduje specifične genske markere koji su povezani sa povećanom prenosivošću virusa, morbiditetom, mortalitetom i sposobnošću izbegavanja prirodnog imuniteta, kao i smanjenom neutralizacijom terapijskim monoklonskim ili vakcinalnim antitelima, smanjenom efikasnošću antivirusne terapije ili dijagnostičkim mogućnostima, označava se kao ,varijanta u istrazi“ (engl. variant under investigation, VUI), odnosno ,varijanta od interesa“ (engl. variant of interest, VOI). Ukoliko je mutacija uslovila da prevalencija novog soja i njegova transmisivnost premašuju nacionalni nivo, označava se kao „varijanta koja zabrinjava“ (engl. variant of concern, VOC), a ukoliko postoje dokazi da je varijanta razvila osobine koje značajno smanjuju efikasnost postojećih mera prevencije i/ili terapije, postaje „varijanta velikih posledica“ (engl. variant of high consequence, VOHC) $(32,33)$.

Do sada postoje četiri globalno priznate varijante koje zabrinjavaju (VOC): Alfa ili B.1.1.7 (UK) linija, Beta ili linija B.1.351 (Južna Afrika), Gama ili linija P.1 (Japan/ Brazil) i Delta ili B.1.617.2 linija (Indija). Prema Evropskom centru za prevenciju i kontrolu bolesti (ECDC), u Velikoj Britaniji je kao VOC označena B.1.1.7, udružena sa E484K i još dve američke varijante (Kalifornija), označene kao Epsilon ili B.1.427 i B.1.429 (34).

Alfa ili B.1.1.7 varijanta (20I/501Y.V1, VOC 202012/01)

Alfa soj ili B.1.1.7 (poznat i kao 20I/501Y.V1, VOC202012/01) predstavlja prvu identifikovanu VOC i to u Ujedinjenom Kraljevstvu (UK) tokom septembra 2020. godine. Ova tzv. britanska varijanta bila je dominantno prisutna u čak 160 zemalja širom sveta, uključujući SAD, gde je identifikovana krajem decembra 2020. godine (35). Danas je Alfa varijanta i dalje predominantno prisutna $u$ globalnoj populaciji, ali skorašnji epidemiološki podaci predviđaju dominaciju novoidentifikovane Delta varijante, zbog njene izuzetno visoke transmisije. Alfa soj se dovodi u vezu sa povećanom prenosivošću (efikasan i brz prenos) i povećanim rizikom od smrtnih ishoda kod hospitalizovanih pacijenata, u poređenju sa ostalim sojevima. Varijanta B.1.1.7 ima mutaciju u RBD S proteina na položaju 501, gde je aminokiselina asparagin $(\mathrm{N})$ zamenjena tirozinom (Y), te se mutacija označava kao N501Y. Ova mutacija se povezuje sa pojačanim afinitetom vezivanja RBD za humani ACE2. Druga mutacija predstavlja deleciju na položaju 69/70, takođe u spajk proteinu, što se povezuje sa izbegavanjem imunskog odgovora (36). Do sada nema dokaza da ova delecija korelira sa težinom kliničke slike, kao i da smanjuje ili utiče na efikasnost vakcine. Treća mutacija sa velikim biološkim značajem nastala je supstitucijom aminokiseline prolin u histidin na poziciji $681(\mathrm{P} 681 \mathrm{H})$, koja uslovljava konformacionu promenu $\mathrm{S}$ proteina u blizini mesta furin polibaznog cepanja na S1/S2 subjedinicu $(22,36)$. 
Februara 2021. godine Javno zdravlje Engleske (engl. Public Health England, PHE) prepoznalo je novu VOC. Radilo se o varijanti B.1.1.7 udruženoj sa E484K mutacijom (VOC - 202102/02) koja je vrlo brzo identifikovana u SAD. Udružena B.1.1.7 + E484K sve do marta 2021. nije bila detektovana u UK, rapidno i kontinuirano se širila svetom izvan ove zemlje. Smatra se da B.1.1.7 varijanta udružena sa E484K mutacijom izbegava neutrališući kapacitet terapijskih monoklonskih antitela (37).

\section{Beta ili B.1.351 varijanta (20H/501Y.V2)}

Beta ili B.1.351 varijanta, iako se pojavila nezavisno od B.1.1.7, poseduje određene zajedničke mutacije koje su identifikovane i u britanskom soju. Prvi put je identifikovana u provinciji Istočni rt u Južnoj Africi u uzorcima koji datiraju od početka oktobra 2020. Isti soj je dokumentovan u Zambiji krajem decembra 2020. godine, u kojoj postaje dominantna varijanta. Južnoafrički soj se ubrzo proširio i na druge delove sveta i do danas je registrovan u 113 zemalja (38). Ova varijanta ima višestruke mutacije u S proteinu, uključujući K417N, E484K i N501Y. Za sada nema dokaza koji impliciraju da ova varijanta ima uticaj na težinu bolesti, ali svakako pokazuje povećanu trasmisivnost. Takođe, postoji opravdana zabrinutost $u$ vezi sa izmicanjem od imunskog odgovora. Mutaciji E484K se pripisuje da utiče na smanjenje efikasnosti poliklonskih i monoklonskih antitela koja se primenjuju u terapiji, kao i da smanjuje efikasnost antitela stvorenih tokom prirodne infekcije i neutrališućih vakcinalnih antitela $(6,38)$.

\section{Gama ili P1 varijanta (20J/501I.V3)}

Varijanta SARS-CoV-2 poznata kao P.1 ili brazilska varijanta, prema novoj nomenklaturi Gama soj, prvi put je identifikovana kod četiri putnika iz Brazila koji su testirani na aerodromu u Japanu (39). U ovom trenutku Gama varijanta je dokumentovana u 64 zemlje sveta. Varijanta ima 17 jedinstvenih mutacija, uključujući tri K417T, E484K i N501Y koje su locirane u RBD S proteina (40). Smatra se da neke od mutacija P.1 varijante utiču na transmisivnost soja i antigenski profil. Imaju i značajan uticaj na redukciju neutrališuće uloge antitela. Visok replikativni "fitness" koji korelira sa visokim "viral load” P1 varijante u određenim klasterima stanovništva nekih gradova u Brazilu, gde je u $42 \%$ svih sekvenciranih uzoraka identifikovana ova varijanta, izazivaju opravdanu zabrinutost zbog visoke prenosivosti virusa, a posebno zbog mogućnosti reinfekcije (6).

\section{B.1.429 i B.1.427 varijante}

Varijante B.1.429 i B.1.427 sa četiri, odnosno dve mutacije u S proteinu, definisane su kao VOC u SAD, odnosno kao VOI ili Epsilon varijante prema SZO, takođe poznate i kao CAL.20C i 20C/S: 452R. Ove varijante su prvi put identifikovane u Kaliforniji, februara 2021. godine, sa prisutnošću u populaciji tog dela sveta većom od $50 \%$. Smatra se da oba soja imaju $20 \%$ veću transmisivnost u odnosu na druge VOC. Takođe, pokazuju umereno smanjenu neutralizaciju pri terapiji antitelima dobijenim iz seruma rekonvalescenata ili antitelima vakcinisanih osoba.

Prema najnovijim podacima ECDC od 22. jula 2021. godine, B.1.429 i B.1.427 varijante se, na osnovu najmanje jednog od sledećih kriterijuma: (1) varijanta više ne cirkuliše, (2) varijanta već dugo kruži bez ikakvog uticaja na ukupnu epidemiološku situaciju i (3) naučni dokazi pokazuju da varijanta nije povezana ni sa jednim svojstvom, smatraju varijantama koje ne eskaliraju (33).

\section{Delta ili B.1.617 varijanta}

Varijanta B.1.617, poznata kao Delta varijanta, prvi put je identifikovana krajem 2020. godine u Indiji. Postoje tri sublinije: B.1.617.2, B.1.617.1 i B.1.617.3, koje imaju različit profil mutacija. Kod svih varijanti su od posebnog značaja one mutacije koje su pozicionirane u NTD i/ili RBD S proteina. Sublinija B.1.617.2 je, ubrzo nakon identifikacije, prepoznata kao varijanta sa visokom transmisivnom sposobnošću, čak više od $60 \%$ u odnosu na Alfa varijantu. Poseduje četiri mutacije u RBD koje se upravo povezuju sa izrazito povećanom sposobnošću virusa za efikasno i brzo prenošenje i imunsku evaziju, ali se smatra da imaju uticaj i na težinu kliničke slike, o čemu za sada nema eksplicitnih dokaza kada je u pitanju B.1.617.1 (Kappa varijanta). Sve sublinije poseduju P681R mutaciju u proteinu šiljka koja je ključna za povećanu prenosivost virusa. Mutacija P681R stimuliše proces polibaznog cepanja $S$ proteina od strane ćelijske furin proteaze ekstenzijom RRAR motiva, što rezultira značajno višim "viral load" Delta varijante, a time i većom sposobnošću za transmisiju i pojačanom patogenošću $(13,41)$. In vitro ispitivanja su pokazala da RBD mutacija 478 (T478K) kod B.1.617.2 varujante pokazuje smanjenu neutralizaciju monoklonskim antitelima, kao i antitelima iz seruma rekonvalescenata (42). Najzad, B.1.617.3 sublinija je otkrivena februara 2021. godine, takođe u Indiji. Sublinije B.1.617.3 i B.1.617.1 za sada su klasifikovane kao VOI (33).

\section{Zaključak}

SARS CoV-2 je već dugo prisutan u svetskoj populaciji, što virusu obezbeđuje da se kontinuirano menja. Pojava novih virusnih varijanti sa novim osobinama, najčešće povoljnim po virus, upravo mu i obezbeđuje tako dug opstanak među ljudima. Sve dok je značajan broj svetske populacije zaražen SARS-CoV-2, mutacije će se i dalje dešavati zbog visokog obima virusne replikacije koja je sklona greškama. Očekivano je da će se nove virusne varijante i dalje pojavljivati i predstavljati rizik za pojavu težih kliničkih slika, menjati performanse vakcina, uspeh antivirusne terapije, mogućnosti da budu identifikovane postojećim dijagnostikama ili će se skrivati i/ili bežati od imunskog odgovora domaćina. Takođe, kocirkulacija glavnih varijanti na istom geografskom području, što se i događa, omogućava virusu takve rekombinacije koje koreliraju sa visokim rizikom za zdravlje ljudi i nastankom različitih posledica. 
Ostaje i dalje da je permanentni monitoring nad pojavom novih SARS-CoV-2 varijanti sekvenciranjem kompletnog virusnog genoma iz uzoraka obolelih širom planete neopodan korak u otkrivanju novih virusnih varijanti i novih karakteristika virusa. Samo ovakav pristup, uz sveobuhvatnu imunizaciju ljudi i dosledno poštovanje epidemijskih mera, predstavlja efikasan put u zaustavljanju pandemije COVID-19.

\section{Literatura}

1. Zhu N, Zhang D,Wang W, Li X, Yang B, Song J, et al. A novel coronavirus frompatients with pneumonia in China, 2019. N Engl J Med. 2020; 382(8):727-33.

2. Zhou P, Yang X. L, Wang X. G, Hu B, Zhang L, Zhang W, et al. A pneumonia outbreak associated with a new coronavirus of probable bat origin. Nature. 2020; 579(7798):270-3.

3. Centers for Disease Control and Prevention. Variants of the virus that causes COVID-19. 2021. Available from: https://www.cdc. gov/coronavirus/2019ncov/variants/index.html.

4. Ayoubkhani D, Khunti K, NafilyanV, Maddox T, Humberstone B, Diamond I, et al. Post-covid syndrome in individuals admitted to hospital with covid-19: retrospective cohort study. BMJ. 2021; 372:n693.

5. World Health Organization (WHO). "Official COVID-19 Information". 2021. (cited 2021. Jul 22). Available from: https:// www.worldometers.info/coronavirus/

6. Buchan W.B,Yao D. J. Severe Acute Respiratory Syndrome Coronavirus 2: The Emergence of Important Genetic Variants and Testing Options for Clinical Laboratories. Clin Microbiol Newsl. 2021; 43(11):89-96.

7. Zhong N.S, Zheng B.J, Li Y.M, Poon L.L.M, Xie Z.H, Chan K.H, et al. Epidemiology and cause of severe acute respiratory syndrome (SARS) in Guangdong, People's Republic of China, in February, 2003. Lancet. 2003; 362(9393):1353-8.

8. Zaki A.M, van Boheemen S, Bestebroer T.M, Osterhaus A.D, Fouchier R.A. Isolation of a novel coronavirus from a man with pneumonia in Saudi Arabia. N Engl J Med. 2012; 367(19):1814-20.

9. Lu R, Zhao X, Li J, Niu P, Yang B, Wu H, et al. Genomic characterisation and epidemiology of 2019 novel coronavirus: Implications for virus origins and receptor binding. Lancet. 2020; 395(10224):565-74.

10. Wu F, Zhao S, Yu B, Chen Y.M, Wang W, Song Z.G, et al. A new coronavirus associated with human respiratory disease in China. Nature. 2020; 579(7798):265-9.

11. Zhou P, Yang X.L, Wang X.G, Hu B, Zhang L, Zhang W, et al. A pneumonia outbreak associated with a new coronavirus of probable bat origin. Nature. 2020; 579(7798):270-3.

12. Kaur N, Singh R, Dar Z, Bijarnia K.R, Dhingra N, Kaur T. Genetic comparison among various coronavirus strains for the identification of potential vaccine targets of SARS-CoV-2. Infect Genet Evol. 2021; 89:104490.

13. Lazarevic I, Pravica V, Miljanovic D, Cupic M. Immune Evasion of SARS-CoV-2 Emerging Variants: What Have We Learnt So Far? Viruses. 2021; 13(7):1192.

14. Kim D, Lee J.Y, Yang J.S, Kim J.W, Kim V.N, Chang H. The architecture of SARS CoV-2 transcriptome. Cell. 2020; 181(4):914-21.

15. Wu A, Peng Y, Huang B, Ding X, Wang X, Niu P, et al. Genome composition and divergence of the novel coronavirus (2019$\mathrm{nCoV}$ ) originating in China. Cell Host Microbe. 2020; 27(3):325-28.

16. Tortorici M.A, Veesler D. Structural insights into coronavirus entry. Adv Virus Res. 2019; 105:93-116.

17. Teoh K.T, Siu Y.L, Chan W.L, Schlüter M.A, Liu C.J, Peiris J.S, et al. The SARS coronavirus E protein interacts with PALS1 and alters tight junction formation and epithelial morphogenesis. Mol Biol Cell. 2010; 21(22):3838-52.

18. Michel C.J, Mayer C, Poch O, Thompson J.D. Characterization of accessory genes in coronavirus genomes. Virol J. 2020; 17(1):131.
19. Huang Y, Yang C, Xu X.F, Xu W, Liu S.W. Structural and functional properties of SARS-CoV-2 spike protein: Potential antivirus drug development for COVID-19. Acta Pharmacol Sin. 2020; 41(9):1141-9.

20. Walls A.C, Park Y.J, Tortorici M.A, Wall A, McGuire A.T, Veesler D. Structure, Function, and Antigenicity of the SARS-CoV-2 Spike Glycoprotein. Cell. 2020; 181(2):281-92.

21. Letko M, Marzi A, Munster V. Functional assessment of cell entry and receptor usage for SARS-CoV-2 and other lineage B betacoronaviruses. Nat Microbiol. 2020; 5(4):562-9.

22. Finkelstein M.T, Mermelstein A.G, Parker Miller E, Seth P.C, Stancofski E.D, Fera D. Structural Analysis of Neutralizing Epitopes of the SARS-CoV-2 Spike to Guide Therapy and Vaccine Design Strategies. Viruses. 2021; 13(1):134.

23. Hoffmann M, Kleine-Weber H, Schroeder S, Kruger N, Herrler T, Erichsen S, et al. SARS-CoV-2 cell entry depends on ACE2 and TMPRSS 2 and is blocked by a clinically proven protease inhibitor. Cell. 2020; 181(2):271-80.

24. Lan J, Ge J, Yu J, Shan S, Zhou H, Fan S, et al. Structure of the SARS-CoV-2 spike receptor binding domain bound to the ACE2 receptor. Nature. 2020; 581(7807):215-20.

25. Wrobel A.G, Benton D.J, Xu P, Roustan C, Martin S.R, Rosentha P.B, et al. SARS-CoV-2 and bat RaTG13spike glycoprotein structures inform on virus evolution and furin-cleavage effects. Nat Struct Mol Biol. 2020; 27(8):763-7.

26. Dhama K, Patel K.S, Sharun K, Pathak M, Tiwari R, Yatoo I.M, et al. SARS-CoV-2 jumping the species barrier: Zoonotic lessons from SARS, MERS and recent advances to combat this pandemic virus. Travel Med Infect Dis. 2020; 37:101830.

27. Parczewski M, Ciechanowicz A. Molecular epidemiology of SARSCoV-2: A review of current data on genetic variability of the virus. Pol Arch Intern Med. 2020; 131(1):63-9.

28. Korber B, Fischer W.M, Gnanakaran S, Yoon H, Theiler J, Abfalterer $\mathrm{W}$, et al. Tracking changes in SARS-CoV-2 spike: Evidence that D614G increases infectivity of the COVID-19 virus. Cell. 2020; 182(4):812-27.

29. Alm E, Broberg E.K, Connor T, Hodcroft E.B, Komissarov A.B, Maurer-Stroh S, et al. Geographical and temporal distribution of SARS-CoV-2 clades in the WHO European Region, January to June 2020. Euro Surveill. 2020; 25(32):2001410.

30. Rambaut A, Holmes E.C, O’Toole Á, Hill V, McCrone J.T, Ruis C, et al. A dynamic nomenclature proposal for SARS-CoV-2 lineages to assist genomic epidemiology. Nat Microbiol. 2020; 5(11):1403-7.

31. World Health Organization (WHO). "Weekly Epidemiological Update on COVID-19 - 1 June 2021". 2021. Available from: https:/www.who.int/publications/m/item/ weekly-epidemiological-update-on-covid-19---1-june-2021.

32. World Health Organization (WHO). "Weekly epidemiological update on COVID-19 - 26 July 2021”. 2021. Available from: https://www.who.int/publications/m/item/ weekly-operational-update-on-covid-19---26-july-2021.

33. European Centre for Disease Prevention and Control (ECDC) (CDC). "SARS-CoV-2 SARS-CoV-2 variants of concern" as of 22 July 2021". 2021. Available from: https://www.google.com/sear$\mathrm{ch}$ ? client $=$ firefox $-\mathrm{b}-\mathrm{d} \& \mathrm{q}=\mathrm{ECDCsars}+\mathrm{cov} 2+$ variants + of + concer $\mathrm{n}+\mathrm{as}+\mathrm{of}+8+\mathrm{july}+2021$.

34. Centers for Disease Control and Prevention (CDC). "SARSCoV-2 Variant Classifications and Definitions". 2021. Available from:https://www.cdc.gov/coronavirus/2019-ncov/cases-updates/ variant-surveillance/variant-info.html.

35. Tang J.W, Tambyah P.A, Hui D.S. Emergence of a new SARSCoV-2 variant in the UK. J Infect. 2021; 82(4):e27-e28.

36. Graha C, Seow J, Huettner I, Khan H, Kouphou N, Acors S, et al. Neutralization potency of monoclonal antibodies recognizing dominant and subdominant epitopes on SARS-CoV-2 Spike is impacted by the B.1.1.7 variant. Immunity. 2021; 54(6):1276-89.

37. Public Health England (PHE). Government Digital Service. "Variants: Distribution of Cases Data". 2021. Available from: https://www.gov.uk/government/publications/covid-19-variants-genomically-confirmed-case-numbers/ variantsdistribution-of-cases-dat. 
38. Tegally H, Wilkinson E, Giovanetti M, Iranzadeh A, Fonseca V, Giandhari J, et al. Detection of a SARS-CoV-2 variant of concern in South Africa. Nature. 2021; 592(7854):438-43.

39. Fujino T, Nomoto H, Kutsuna S, Ujiie M, Suzuki T, Sato R, et al. Novel SARS-CoV-2 variant in travelers from Brazil to Japan. Emerg Infect Dis. 2021; 27(4):1243-5.

40. Sabino E.C, Buss L.F, Carvalho M.P.S, Prete C.A.J, Crispim M.A.E, Fraiji N.A, et al. Resurgence of COVID-19 in Manaus, Brazil, despite high seroprevalence. Lancet. 2021; 397(10273):452-55.
41. Singh J, Rahman A.S, Nasreen Z, Ehtesham Z.N, Hira S, Hasnain S. E. SARS-CoV-2 variants of concern are emerging in India. Nat Med. 2021; 27(7):1131-3.

42. Liu Z, VanBlargan L.A, Bloyet L.M, Rothlauf P.W, Chen R.E, Stumpf $S$, et al. Identification of SARS-CoV-2 spike mutations that attenuate monoclonal and serum antibody neutralization. Cell Host Microbe. 2021; 29(3):477-88. 